Anna Saignes

Uniwersytet Grenoble-Alpes

\title{
Czy strukturalizm zabił literaturę (we Francji)? Od efektu rzeczywistości do powrotu rzeczywistości
}

\author{
Did Structuralism Kill Literature (in France)? From the Reality Effect to the Return \\ to Reality
}

\begin{abstract}
In the field of the literary studies in France structuralism was strongly connected with the assumption that literature doesn't describe reality, i.e. that it is "irreferential". For some time the words "reality", "history" and the question "what literature is for?" have more and more often appeared in the titles of the $\mathrm{PhD}$ theses, conferences, and essays on literature. Such titles demonstrate that the researchers are strongly interested in such problems as the correlations between literature, history and social sciences, or between literature and ethics. These tendencies, of course, are not confined to France and Frenchlanguage areas. In France, however, they have a specific nuance: an assumption that literature has something in common with a real world seems impossible without preliminary confrontation with structuralism and its characteristic axiom of "intransitiveness" of literature. The article offers a review of the most significant positions in the debate held since the end of last century.
\end{abstract}

Keywords: French structuralism, meaning and role of literature, literature and reality

Streszczenie: Na obszarze francuskich badań literaturoznawczych strukturalizm był silnie związany z założeniem, że literatura nie opisuje rzeczywistości, że jest „niereferencyjna”. Od pewnego czasu słowa „rzeczywistość”, „historia” i pytanie: „do czego służy literatura?” coraz częściej pojawiają się w tytułach doktoratów, konferencji i esejów poświęconych literaturze. Podobne tytuły świadczą o bardzo silnym zainteresowaniu francuskich badaczy takimi problemami, jak korelacje między literaturą, historią i naukami społecznymi lub literaturą i etyką. Wymienione tendencje nie ograniczają się oczywiście do obszaru francuskiego ani francuskojęzycznego. We Francji posiadają one jednak specyficzny niuans: założenie, że literatura ma coś wspólnego ze światem rzeczywistym, nie wydaje się możliwe bez wstępnego rozliczenia ze strukturalizmem i charakterystycznym dla niego aksjomatem „nieprzechodniości” literatury. Niniejszy artykuł proponuje przegląd ważniejszych głosów w dyskusji toczącej się od końca poprzedniego stulecia.

Słowa kluczowe: strukturalizm francuski, sens i zadania literatury, literatura i rzeczywistość 
Główna trudność, którą napotyka każda próba oceny strukturalizmu, tkwi w zróżnicowaniu tego niezwykle wpływowego nurtu. Wcielenia strukturalizmu różnią się w przestrzeni, w czasie i przyjmują odrębne formy w poszczególnych dyscyplinach. Co więcej, główni aktorzy strukturalistycznego prądu sami często proponowali w ciągu kilku lat bardzo różniące się od siebie postulaty. A jednak, przynajmniej w wypadku Francji, niektóre pojęcia szczególnie utrwaliły się w pamięci kilku pokoleń literaturoznawców i ich studentów, urastając $\mathrm{w}$ ten sposób do rangi symbolu całego prądu. Jednym z takich pojęć jest niewątpliwie „efekt rzeczywistości” Rolanda Barthes'a, kategoria opisana w eseju wydanym pod takim właśnie tytułem w 1968 roku ${ }^{1}$. „Efekt rzeczywistości” - Barthes podaje jako przykład opis barometru wiszącego w salonie Pani Aubin w opowiadaniu Czyste serce Gustave'a Flauberta i drzwiczek w celi Charlotty Corday w Histoire de France („Historia Francji”) Jules'a Micheleta - to zapis, którego „nie uzasadnia żadna (nawet najbardziej niebezpośrednia) funkcja” w danej opowieści, zapis „nieznaczący” w tkaninie narracji. Podobny zapis wywołuje u czytelnika - tak twierdzi Barthes - wrażenie, że ma on do czynienia z rzeczywistym lub rzeczywistością (le „réel"). Wrażenie takie jest jednak tylko zjawiskiem, które Barthes nazywa „złudzeniem referencjalnym" (illusion référentielle). Oto przedostatni i wręcz powszechnie znany akapit eseju w tłumaczeniu Michała Pawła Markowskiego:

Prawda tego złudzenia jest taka, że „rzeczywistość”, wyeliminowana z wypowiedzi realistycznej jako znaczone denotacji, powraca do niej jako znaczone konotacji. Gdy tylko owe szczegóły zdają się bezpośrednio denotować rzeczywistość, tak naprawdę mogą one jedynie - nic o tym nie wspominając - ją oznaczać. Barometr Flauberta, drzwiczki Micheleta w końcu mówią tylko: jesteśmy rzeczywiste. To właśnie kategoria „,rzeczywistości” (a nie jej przygodna treść) jest oznaczona. Innymi słowy, prawdziwym znaczącym realizmu, na korzyść samego przedmiotu odniesienia, jest nieobecność znaczonego. Tak wytwarza się efekt rzeczywistości, będący podstawą niewyznanego prawdopodobieństwa, tworzącego estetykę najważniejszych dzieł nowoczesności².

Emblematyczny dla całego francuskiego strukturalizmu charakter „pojęcia rzeczywistości” świadczy o tym, jak bardzo strukturalizm we francuskich badaniach o literaturze związany był z założeniem, że literatura nie opisuje rzeczywistości, że jest „niereferencyjna” (non-référentielle), „nieprzechodnia” (intransitive), że - inna strukturalistyczna popularna fraza - nie jest „opowiadaniem o przygodzie”, lecz „przygodą opowiadania”. Upraszczając, według

1 R. Barthes, L'effet de réel. Artykuł ukazał się po raz pierwszy w „Communications” 1968, nr 11, s. 84-89. Po polsku: tenże, Efekt rzeczywistości, tłum. M.P. Markowski, „Teksty Drugie” 2012, nr 4, s. 119-126.

2 J. Ricardou, Problemes du nouveau roman, Paris 1967, s. 111 [tłum. fragm. - A.S.]. 
strukturalistów czytamy tylko po to, aby zaobserwować wewnętrzną organizację tekstu i ujawnić ukryte w jego tkance odniesienia do innych tekstów, to znaczy jego charakter intertekstualny czy też hipertekstualny w terminologii Gérarda Genette’a. Od pewnego czasu słowa „rzeczywistość”, „historia” i pytanie: „do czego służy literatura?” coraz częściej pojawiają się w tytułach doktoratów, konferencji i esejów poświęconych literaturze. Podobne tytuły świadczą o bardzo silnym zainteresowaniu francuskich badaczy takimi problemami, jak korelacje między literaturą, historią i naukami społecznymi lub literaturą i etyką. Wymienione tendencje nie ograniczają się oczywiście do obszaru francuskiego ani francuskojęzycznego. We Francji cechuje je jednak specyficzny niuans: założenie, że literatura ma coś wspólnego ze światem rzeczywistym, nie wydaje się możliwe bez wstępnego rozliczenia ze strukturalizmem i charakterystycznym dla niego aksjomatem „nieprzechodniości” literatury. Oto kilka z ważniejszych głosów francuskich badaczy w toczącej się od końca poprzedniego stulecia dyskusji o sensie i zadaniach literatury.

Zakwestionowanie strukturalistycznego paradygmatu, przynajmniej niektórych z jego najważniejszych założeń, jak przypomina Thomas Pavel, zaczyna się już około roku 1980 i zostaje przeprowadzone przez historyków, filozofów i krytyków literackich, takich jak Pierre Nora, Vincent Descombes, Tzvetan Todorov, Marc Fumaroli. W dziedzinie badań literackich najgłośniejszą rozprawą na ten temat jest z pewnością Demon teorii. Literatura a zdrowy rozsadek Antoina Compagnona ${ }^{3}$, wydana jednak dopiero w 1998 roku. Sam tytuł zapowiada już treść rozprawy: nawiązuje on do opowiadania Edgara Allana Poego, The Imp of the Perverse, po francusku Le démon de la perversité (w tłumaczeniu Charlesa Baudelaire’a), a po polsku Bies przewrotności (w tłumaczeniu Stanisława Wyrzykowskiego). Bies przewrotności w opowiadaniu Poego to siła, która zmusza człowieka, aby zadziałał wbrew swoim własnym interesom, a więc siła prowadząca do autodestrukcji. Dla Compagnona teoria literacka ma w sobie właśnie coś z takiej siły. Zdrowy rozsądek (sens commun), określenie występujące w podtytule rozprawy, jest przeciwieństwem zgubnej "teorii”. To istniejąca u wszystkich czytelników zdolność do wydawania sądów bez nadmiernego teoretyzowania, a nawet, jak stwierdza Kartezjusz w Rozprawie o metodzie, „to rzecz ze wszystkich na świecie najlepiej rozdzielona”. Antoine Compagnon wspomina jednak teoretyczną i pojęciową gorączkę,

3 A. Compagnon, Le Démon de la théorie. Littérature et sens commun, Paris 1998. Wydanie polskie: tenże, Demon teorii. Literatura a zdrowy rozsądek, tłum. T. Stróżyński, Gdańsk 2010.

${ }^{4}$ R. Descartes, Rozprawa o metodzie wtaściwego kierowania rozumem i poszukiwania prawdy w naukach, tłum. T. Żeleński (Boy), Warszawa 1980, s. 29. 
która ogarnęła Francję w latach 1960 i 1970, z humorem i nostalgią. Zarażeni strukturalistyczną chorobą literaturoznawcy postanowili raz na zawsze skończyć z serią komunałów charakteryzujących potoczny dyskurs o literaturze. Oto najczęściej spotykane z nich: intencja autora decyduje o znaczeniu teks$\mathrm{tu}$, literatura opowiada o świecie, istotą literatury jest styl. Compagnon poddaje krytycznej analizie podstawowe założenia teorii literackiej, które miały na celu definitywne odrzucenie uproszczen. Według strukturalistów, przypomina Compagnon, autor nie decyduje o znaczeniu swojego tekstu, literatura nie opowiada o świecie, stanowi byt samowystarczalny, czytelnik jest współautorem tekstu, styl nie istnieje, a kanon literacki jest wynikiem arbitralnego wyboru lub przypadku. Postulaty te - dowodzi Compagnon - szybko jednak ukazują sprzeczności, na jakich są zbudowane. Główna z nich brzmi następująco: literatura nie mówi o świecie, ponieważ język go nie wyraża, ale stwierdzenie, że język nie opowiada o świecie, wymaga przecież założenia, że opowiada. Innymi słowy, teoria zaprzecza istnieniu funkcji poznawczej języka, a jednocześnie z niej korzysta. Teoria przeczy w ten sposób samej sobie, a zdrowy rozsądek wychodzi zwycięsko z konfrontacji i nadal uczestniczy w procesie czytania. Oto, pełne humoru, podsumowanie rozprawy:

Oczywiście, autor umarł, literatura nie ma nic wspólnego ze światem, synonimia nie istnieje, wszystkie interpretacje są możliwe, kanon został ustalony bezprawnie, a jednak nadal czytamy biografie pisarzy, utożsamiamy się z postaciami powieści, chodzimy tropem Raskolnikowa po ulicach Petersburga, wolimy Madame Bovary od Fanny, a sam Barthes przed snem zanurzał się z rozkoszą w Hrabim Monte-Christo ${ }^{5}$.

Antoine Compagnon nie twierdzi jednak bynajmniej, że o propozycjach, które zrodziły się w czasach teoretycznej gorączki, należy po prostu zapomnieć. Teoria literacka stymuluje refleksję o literaturze pod warunkiem, że nie przekształca się w dogmat i w wyjaławiającą technikę. Teoretyczna gorączka niewątpliwie podważyła kilka pewników i pozwoliła na lepsze zrozumienie literatury. Samo powodzenie, z jakim spotkała się we Francji książka Compagnona, świadczy już o tym, że odpowiedziała ona na pewne oczekiwania, wyrażając pogląd powszechnie przyjęty, który jednak nie został wcześniej wyraźnie sformułowany.

O wiele ostrzejsze podsumowanie strukturalizmu przeprowadza Tzvetan Todorov w eseju o dobitnie brzmiącym tytule: La Littérature en péril6 („Literatura zagrożona”) wydanym dziesięć lat po Demonie teorii Compagnona. Ojciec założyciel strukturalizmu, słynący z antologii tekstów formalistów rosyjskich w tłumaczeniu francuskim ${ }^{7}$ i z rozprawy o literaturze fantastycznej ${ }^{8}$,

\footnotetext{
5 A. Compagnon, Demon teorii, dz. cyt., s. 307.

6 T. Todorov, La Littérature en péril, Paris 2007.

7 Tenże, Théorie de la littérature. Textes des formalistes russes, Paris 1965.

8 Tenże, Introduction à la littérature fantastique, Paris 1970.
} 
współtwórca z Gérardem Genette’em czasopisma „Poetique”, które wydało najbardziej dla nurtu znaczące teksty, oskarża strukturalizm o spowodowanie spadku zainteresowania literaturą, którego nie sposób nie zauważyć na początku XXI wieku. Compagnon ubolewa, że stymulująca teoria utrwaliła się w postaci dogmatu. Krytyka Todorova jest przede wszystkim wymierzona w nauczanie literatury w szkole i na uniwersytecie, które - w roku 2007 - ma głównie na względzie metody analizy literatury, a nie utwór literacki potraktowany jako przykład przekonujący o sprawności metod. Oficjalne teksty zalecają nauczanie o gatunkach, rejestrach, modalnościach, funkcjach językowych i modelach aktancjalnych. Mimo kilku drobnych różnic strukturalizm i poststrukturalizm, według Todorova, traktują literaturę w bardzo podobny sposób: zadają pytanie o związki utworu literackiego z rzeczywistością i wartościami, ale odpowiadają na nie twierdzeniem, że utwór nie może nic na te tematy powiedzieć (strukturaliści), że jest zawsze niespójny i że wciąż podważa swoją własną wartość (poststrukturaliści). Według Todorova zaś, „[p]odobnie do filozofii, podobnie do nauk społecznych, literatura jest myśleniem i wiedzą o świecie psychicznym i społecznym, w którym żyjemy"'. Podobnego zdania jest Jacques Bouveresse. W rozprawie pod tytułem La Connaissance de l'écrivain. Sur la littérature, la vérité et la vie ${ }^{10}$ („Poznanie pisarza. O literaturze, prawdzie i życiu”) z 2008 roku o spadek zainteresowania literaturą obwiniani są indoktrynowani przez strukturalizm nauczyciele i wykładowcy, którzy odcięli literaturę od znaczenia i świata, aby zrobić z niej autonomiczny byt. W wywiadzie udzielonym tygodnikowi „L’Express” tuż po publikacji szkicu Bouveresse, profesor filozofii w Collège de France, tłumaczy, że już od wielu lat chciał napisać książkę o poznawczych właściwościach literatury, lecz długo się wahał z powodu „atmosfery dogmatyzmu, a nawet terroru, jaka panowała do niedawna w krytyce i teorii literackiej"11. Do podobnego wniosku dochodzi również Antonie Compagnon w tekście pod tytułem La littérature pour quoi faire („Literatura, dlaczego?”), będącym jego wykładem inauguracyjnym w Collège de France, gdzie objął w roku 2006 katedrę literatury francuskiej nowoczesnej i współczesnej. Nie sposób, według Compagnona, nie zauważyć, iż spadek zainteresowania literaturą jest w dużej mierze konsekwencją czasów, kiedy „stwierdzenie, że literatura posiada jakąkolwiek władzę, było nieprzyzwoite (obscène), ponieważ panowało przekonanie, że literatura nie służy do niczego"12. Przestała ona wtedy być

9 Tenże, La Littérature en péril, dz. cyt., s. 72-73.

${ }_{10} \mathrm{~J}$. Bouveresse, La Connaissance de l'écrivain. Sur la littérature, la vérité et la vie, Marseille 2008 .

${ }_{11}$ Tenże, J'ai toujours été profondément révulsé par le moralisme, https://www.lexpress.fr/culture/livre/jacques-bouveresse-j-ai-toujours-ete-profondement-revulse-par-le-moralisme_814050. html, dostęp: 10.05.2018 [tłum. fragm. - A.S.].

12 A. Compagnon, La littérature pour quoi faire? Leçon inaugurale au collège de France, http://www.college-de-france.fr/site/antoine-compagnon/Parution-de-l-edtion-electr_2.htm, dostęp: 10.05.2018 [tłum. fragm. - A.S.]. 
jednym z podstawowych sposobów zdobywania wiedzy, określania wartości, myślenia o człowieku i o świecie. Dla Compagnona, podobnie jak dla Bouveressa, główny przywilej literatury polega na umożliwieniu czytelnikowi przeżycia tego, co przeżywają inni. W ten sposób pogłębia ona i polepsza nasz stosunek do bliźnich. Do takiej wiedzy daje dostęp tylko dzieło literackie.

Według Todorova strukturalizm dużo zawinił, ale przecież nie wziął się znikąd. W poszerzonej perspektywie twierdzenie o autonomiczności utworu literackiego staje się jedynie punktem kulminacyjnym zjawiska, którego korzeni należy szukać dużo wcześniej, na przełomie XVIII i XIX wieku, kiedy rodzi się pojęcie estetyki. William Marx, krytyk i profesor literatury porównawczej na Uniwersytecie Paris X Nanterre, w eseju pod tytułem L'Adieu à la littérature. Histoire d'une dévalorisation („Pożegnanie z literaturą. Opowieść o dewaloryzacji”) o zabicie literatury oskarża... literaturę, szczególnie koncepcję literatury wynikającą z - lub towarzyszącą - twórczości Charles’a Baudelaire’a, Gustave'a Flauberta, Stephane'a Mallarmégo i Marcela Prousta. Dla Williama Marxa kryzys literatury zaczyna się również z końcem XVIII wieku. Proces składa się z trzech etapów: ekspansja, autonomizacja, dewaloryzacja. Strukturalizm był po prostu punktem, do którego dzieje literatury dążyły już od dwóch stuleci. Moment krytyczny nastąpił, kiedy Roland Barthes w Przyjemności tekstu (1973) ogłosił, że tekst krytyka jest również literaturą:

Pozbawiona wszystkich funkcji, które określały jej tożsamość, utożsamiona z literaturą w momencie, kiedy ta ostatnia straciła wszelką wartość, krytyka zostaje ostatnią ofiarą deprecjacji literatury i stacza się z nią w przepaść. (...) Tak dzieje się we Francji, gdzie autonomizacja literatury w stosunku do społeczeństwa została posunięta dalej niż w innych krajach ${ }^{13}$.

Podobnie Dominique Maingueneau, w eseju o tytule parodiującym tytuł słynnego szkicu krytycznego Prousta, Contre Saint-Proust. Ou la fin de la littérature $^{14}$ („Przeciwko Świętemu Proustowi, czyli koniec literatury”), odpowiedzialnością za śmierć literatury obarcza samego Prousta, który narzucił podział na ,ja” człowieka żyjącego w świecie i ,ja” pisarza, objawiające się w literaturze, czyli w „prawdziwym życiu”. Podział ten szczególnie spodobał się strukturalistom. A przecież, twierdzi Maingueneau, literatura należy do praktyk konwersacyjnych i stanowi specyficzny rodzaj interakcyjności komunikacyjnej. Podział na literaturę i świat jest w tym świetle pozbawiony sensu. Trzeba zerwać z myśleniem o literaturze opartym na podziale zaproponowanym przez Prousta i rozpowszechnianym przez strukturalistów, nawołuje Dominique Maingueneau.

13 W. Marx, L'Adieu à la littérature. Histoire d'une dévalorisation, Paris 2005, s. 163 [tłum. fragm. - A.S.].

${ }^{14}$ D. Maingueneau, Contre Saint-Proust, Paris 2006. 
Strukturalizm, choć poddany ostrej krytyce, jest więc coraz częściej rozumiany jako logiczne ogniwo $\mathrm{w}$ dziejach literatury i krytyki francuskiej. Czy oznacza to, że strukturalizm został ostatecznie rozliczony i należy już do historii? Coraz częściej uważa się, iż ograniczenie miejsca literatury w dzisiejszym świecie wynika z konkurencji innych mediów. Podobne podejście do kwestii spadku zainteresowania literaturą i zakwestionowania jej roli w kulturze minimalizuje rolę strukturalizmu. Do takiego zdania dochodzą Laurent Demanze i Dominique Viart, profesorowie współczesnej literatury francuskiej, we wstępie do zbiorowego tomu pod tytułem Fins de la littérature. Esthétiques et discours de la fin ${ }^{15}$ („Końce literatury. Estetyki końca i dyskursy o końcu"), opublikowanym w roku 2012. Strukturalizm przestaje być perwersyjnym demonem.

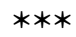

Ponieważ literatura choruje na utratę więzi ze światem, aby wskrzesić zainteresowanie nią, należy przypomnieć o istnieniu tej właśnie więzi. Tak uważają Compagnon, Todorov, Bouveresse, Maingueneau. Pogląd ten owocuje nie tylko nowymi kierunkami w badaniach literackich, ale także skupieniem uwagi na innym korpusie tekstów. Wydana w roku 2005 książka pod tytułem La Littérature française au présent. Héritage, modernité, mutations („Literatura francuska w czasie teraźniejszym. Spuścizna, nowoczesność, przemiany”), autorstwa Bruna Verciera i Dominque’a Viarta, została przywitana jako pierwszy ambitny bilans dotyczący literatury ostatnich 25 lat. We wstępie autorzy przeprowadzają nieuniknioną krytykę strukturalizmu:

już na początku lat 1980 literatura nabiera dystansu wobec poprzedzających dziesięcioleci. Krytyka strukturalistyczna i ostatnie awangardy, które zdominowały przestrzeń literacką od początku lat pięćdziesiątych XX wieku do końca lat siedemdziesiątych XX wieku, wystrzegały się subiektywności i realizmu. Opierały się one na teoriach wypracowanych $w$ dziedzinie nauk społecznych - lingwistyce, psychoanalizie itd. - i na przekonaniu, że postaci literackie są tworami ze słów o - jak mówił Valery - „papierowych wnętrzach”. Uważały, że przypisywanie tym ostatnim jakichkolwiek roszczeń do ekspresji podmiotu lub do przedstawiania rzeczywistości było zupełnie iluzoryczne. Literatura stopniowo przekonała się, że nie może uciec od zamknięcia, jakie charakteryzuje język, i w ten sposób stała się swoim własnym zwierciadłem, swoim własnym ulubionym terenem zabaw i badań. $Z$ tą chwilą skazała się na ograniczenie do konstrukcji formalnych, do zabaw z językiem i strukturami ${ }^{16}$.

15 Fins de la littérature. Esthétiques et discours de la fin, red. L. Demanze, D. Viart, Paris 2012.

${ }^{16}$ La Littérature française au présent. Héritage, modernité, mutations, red. D. Viart, B. Vercier, Paris 2008 (pierwsze wydanie 2005), s. 15 [tłum. fragm. - A.S.]. 
Na tym się jednak nie skończyło, twierdzą Vercier i Viart. Doświadczenia jednostki i pytania dotyczące społeczności ponownie narzuciły się pisarzom, zarówno tym należącym do starszych pokoleń, którzy wcześniej się tymi problemami nie interesowali, jak i tym młodym, dopiero zaczynającym karierę pisarską, u których żyłka literacka była nieodłączna od chęci czy też potrzeby opowiedzenia o sobie, o świecie, o pamięci historycznej lub osobistej. Zmiany w literaturze i krytyce literackiej są zauważalne już na początku lat osiemdziesiątych, utrzymują autorzy, lecz nie zostały dotąd (to znaczy przed rokiem 2005) opisane jako spójne i powszechne zjawisko. Polegają one głównie na ponownym odkryciu komunału, jak by to powiedział Antoine Compagnon, że literatura zawiera wiedzę o człowieku i społeczeństwie. Rozprawa składa się z dwóch części. W pierwszej z nich autorzy proponują przegląd dominujących od lat osiemdziesiątych XX wieku form i zagadnień. Są nimi: écriture de soi (dosłownie „pisanie o sobie”, czyli formy autobiograficzne, dzienniki, notatniki), pisarstwo o historii (wojny i obozy), pisarstwo o świecie. Druga zawiera studium o ewolucji gatunków. Słowa „podmiot”, „rzeczywistość”, „Historia”, „zaangażowanie” - zauważają autorzy - powracają do dyskursu o literaturze, tym razem wyłącznie w formie nierozwiązanych zagadnień i pytań bez odpowiedzi. Viart i Vercier określają literaturę po roku 1980 przymiotnikiem „przechodnia”, aby odciąć się w ten sposób od „nieprzechodności” literatury głoszonej przez wyznawców strukturalizmu.

Nie wszyscy jednak podzielają dziś przekonanie, że literatura jest myśleniem i wiedzą o świecie. Pytania, czy i pod jakim warunkiem literatura może opowiedzieć o historii, stać się świadectwem, spełnić wymagania etyczne związane na przykład z pisaniem o obozach lub subalternach, są obecne i nadal poddane dyskusji. Literatura jest więc wciąż posądzana o fałsz. We wstępie do numeru czasopisma „Europe”, poświęconemu świadectwu, Frédérik Detue i Charlotte Lacoste odmawiają literaturze wszelkiej legitymacji w opowiadaniu o wojnach, ludobójstwach i obozach: „powieściopisarze świadkowie, przekonani, że wolność twórcza anuluje wymagania narzucone przez doświadczenie” i że w ten właśnie sposób dokonuje się „transsubstancjacja rzeczywistości w sztukę", przyznali sobie prawo do „wymyślania prawdy”" ${ }^{17}$. Powieść daje kłamliwy obraz wojny (i rzeczywistości w ogóle). Dla autorów szkicu jedynie świadectwo, w bardzo ścisłym tego słowa znaczeniu, jest właściwą literaturą. Innymi słowy, znaczna większość tekstów, które od dwustu lat nazywamy literaturą, nie należy do literatury. Nie sposób nie dostrzec w proponowanym przez autorów zaostrzonym podziale na literaturę ( $\mathrm{w}$ tradycyjnym tego słowa znaczeniu) i świadectwo (które, jako jedyne, oferuje dostęp do prawdy) śladów strukturalistycznych aksjomatów z lat sześćdziesiątych i siedemdziesiątych XX wieku o „nieprzechodności” literatury.

${ }_{17}$ F. Detue, Ch. Coste, Ce que le témoignage fait à la littérature, „Europe” 2016, nr 10411042, s. 10 [tłum. fragm. - A.S.]. 
Ciekawy głos w debacie stanowi esej historyka Ivana Jablonki, autora bogato udokumentowanej i zarazem fascynującej opowieści o losach dziadka i babci, polskich Żydów i komunistów, Histoire des grands-parents que je n’ai pas eu („Opowieść o dziadku i babci, których nie miałem”). W eseju pod prowokującym tytułem L'Histoire est une littérature contemporaine. Manifeste pour les sciences sociales („Historia jest literaturą współczesną. Manifest dla nauk społecznych") Jablonka stara się pogodzić nauki społeczne z literaturą, przyznając w ten sposób literaturze zdolność do mówienia prawdy o świecie i do zrozumienia zarówno przeszłości, jak i teraźniejszości: „Pogodzić nauki społeczne i twórczość literacką to oznacza pisać w sposób nieskrępowany, autentyczny, rozmyślny, nie po to, aby zrezygnować z naukowej ścisłości, lecz wręcz przeciwnie, aby tę ostatnią wzmocnić” ${ }^{18}$. Aby pogodzić skłócone siostry, którymi są nauki społeczne i literatura, Jablonka śledzi ich burzliwe związki, zaczynając od starożytności, kiedy literatura - która się jeszcze literaturą nie nazywała - i historia - która nie była jeszcze dyscypliną naukową - współpracowały ręka w rękę. Dzisiaj ta kiedyś harmonijna i owocna relacja poddana jest podwójnemu zagrożeniu: $\mathrm{z}$ jednej strony zredukowanie historii do literatury (którego skrajnym objawem był „zwrot lingwistyczny”); z drugiej, skrajna separacja między naukami społecznymi i literaturą. Separacja ta skazuje nauki społeczne na nudziarstwo, a literaturę na opowiadanie o samej sobie. W obydwu wypadkach zarówno nauki społeczne, jak i literatura mają dużo do stracenia. Ivan Jablonka podąża więc drogą wskazaną przez Paula Veyne'a i Michela de Certeau. Pisarstwo oferuje korzyści epistemologiczne właśnie dlatego, że nieadekwatny do świata język kryje w sobie nieskończone zasoby, aby wywiązać się z trudnego zadania, jakim jest wyrażenie prawdy o świecie. Aby lepiej zrozumieć, w jaki sposób literatura opowiada o świecie, Ivan Jablonka zachęca do wzięcia pod uwagę korpusu utworów dotąd pozostawionego na uboczu przez francuskich badaczy literatury, którzy na szczycie hierarchii gatunków umieścili powieść. Ten nieco zlekceważony i nawet wzgardzony dotąd korpus Ivan Jablonka określa mianem littérature du réel, dosłownie „literatura rzeczywistości”, będącym zapewne odpowiednikiem dawno już istniejącego w polskiej terminologii wyrażenia „literatura faktu". Na liście tekstów, którymi wspomniany historyk chciałby zainteresować francuskich krytyków, znajdują się między innymi reportaże Ryszarda Kapuścińskiego. Podobne teksty, zdaniem Jablonki, zapraszają do refleksji nad zmiennością konturów tego, co nazywamy literaturą i płynnością granic między literaturą, dokumentem, dokumentem osobistym, dziennikarstwem lub świadectwem. Szkic Jablonki jest niewątpliwie obroną i uświetnieniem literatury. A jednak po przeczytaniu rozprawy trudno nie zadać sobie następującego pytania: czy przeniesienie uwagi na zaniedbany dotąd (we Francji) korpus

18 I. Jablonka, L'Histoire est une littérature contemporaine. Manifeste pour les sciences sociales, Paris 2014, s. 8. 
tekstów „literatury faktu” nie oznacza, że zdolność literatury, w dawnym tego słowa znaczeniu, silnie związanym z pojęciem fikcji, budzi wciąż sceptycyzm?

Dzieje literatury i literaturoznawstwa we Francji od drugiej połowy XX wieku można opisać jako stopniowy powrót znaczącego, po brutalnym jego wygnaniu, opisanym przez Rolanda Barthes'a. We Francji krytyka (francuskiego) strukturalizmu stanowi do dziś preludium każdej refleksji o literaturze. Dzisiaj jeszcze badacz literatury czuje się zobowiązany określić swoje stanowisko w dyskusji o relacjach literatury i rzeczywistości, nawet jeżeli w ostateczności chodzi o potwierdzenie tej relacji. Komunał, zgodnie z którym literatura jest źródłem wiedzy o świecie, zawsze wymaga pewnego usprawiedliwienia. A może to właśnie autonomiczność literatury stała się dzisiaj komunałem? Kolejne stulecie rozpoczyna się pod znakiem powrotu podmiotu i rzeczywistości. Oczywiście jest dzisiaj jasne, że strukturalizm nie zabił literatury. Miejsce i rola literatury w kulturze marginalizują się przede wszystkim w wyniku supremacji autorytetu nauk ścisłych i konkurencji innych mediów. Strukturalizm bezsprzecznie zmienił - na lepsze - podejście do dzieła literackiego: skupił uwagę na tekście, nakłonił do szukania odrębnego podejścia - czy też odrębnych podejść, ponieważ jest ich niewątpliwie wiele - do literatury, która, choć zawiera wiedzę o świecie, nie wyraża jej w ten sam sposób, jak socjologia, historia, filozofia, psychologia lub psychoanaliza (nawet jeżeli granice między tymi dziedzinami są płynne). Prawie wszyscy zgadzają się dzisiaj z tezą, że strukturalizm był bardzo owocnym momentem $\mathrm{w}$ dziejach literatury i krytyki, a teoretyczna gorączka okazała się w ostateczności stymulująca. Pożegnanie ze strukturalizmem trwa w pewnym sensie do dzisiaj i zmusza do nowej definicji literatury. Sam ten fakt świadczy już o ogromnej wpływowości nurtu.

\section{Bibliografia}

Barthes R., Efekt rzeczywistości, tłum. M.P. Markowski, „Teksty Drugie” 2012, nr 4.

Barthes R., L'effet de réel, „Communications” 1968, nr 11.

Bouveresse J., J'ai toujours été profondément révulsé par le moralisme, https://www. lexpress.fr/culture/livre/jacques-bouveresse-j-ai-toujours-ete-profondement-revulse-par-le-moralisme_814050.html, dostęp: 10.05.2018.

Bouveresse J., La Connaissance de l'écrivain. Sur la littérature, la vérité et la vie, Marseille 2008 . 
Compagnon A., Demon teorii. Literatura a zdrowy rozsądek, tłum. T. Stróżyński, Gdańsk 2010.

Compagnon A., Le Démon de la théorie. Littérature et sens commun, Paris 1998.

Compagnon A., La littérature pour quoi faire? Leçon inaugurale au collège de France, http://www.college-de-france.fr/site/antoine-compagnon/Parution-de-1-edtion-electr_2.htm, dostęp: 10.05.2018.

Descartes R., Rozprawa o metodzie wtaściwego kierowania rozumem i poszukiwania prawdy w naukach, tłum. T. Żeleński (Boy), Warszawa 1980.

Detue F., Coste Ch., Ce que le témoignage fait à la littérature, „Europe” 2016, nr 1041-1042.

Fins de la littérature. Esthétiques et discours de la fin, red. L. Demanze, D. Viart, Paris 2012 .

Jablonka I., L'Histoire est une littérature contemporaine. Manifeste pour les sciences sociales, Paris 2014.

La Littérature française au présent. Héritage, modernité, mutations, red. D. Viart, B. Vercier, Paris 2008.

Maingueneau D., Contre Saint-Proust, Paris 2006.

Marx W., L'Adieu à la littérature. Histoire d'une dévalorisation, Paris 2005.

Ricardou J., Problèmes du nouveau roman, Paris 1967.

Todorov T., La Littérature en péril, Paris 2007.

Todorov T., Introduction à la littérature fantastique, Paris 1970.

Todorov T., Théorie de la littérature. Textes des formalistes russes, Paris 1965. 